\title{
GYPSOPHILA PERFOLIATA (CARYOPHYLLACEAE) IN POLAND
}

\author{
WacŁaw Bartoszek \& Alina StachurSKa-Swakoń ${ }^{1}$
}

\begin{abstract}
Gypsophila perfoliata L. is a maritime sand-dune species naturally occurring in Asia and southeastern Europe. In Europe it also is found in ruderal habitats rarely, mainly along railway lines. In Poland the species was first recorded in the 1950s; it was found only at railway stations where iron ore was offloaded from the Kryvyi Rih region, Ukraine. Recently it was found in a new type of habitat: the roadside of a main road in the Carpathians. The paper characterizes the current status, distribution and habitat spectrum of this alien species in Poland.
\end{abstract}

Key words: alien species, distribution, Gypsophila perfoliata, habitat, Poland, synanthropization

Wacław Bartoszek \& Alina Stachurska-Swakoń, Institute of Botany, Jagiellonian University, Kopernika 27, $31-501$ Kraków, Poland; e-mail: waclaw.bartoszek@uj.edu.pl \& alina.stachurska-swakon@uj.edu.pl

\section{INTRODUCTION}

The appearance of alien species in local floras is a process dating back to the beginning of agriculture (e.g., Kornaś 1981). The current proportion of non-native species in the floras of individual European countries varies, numbering from $\mathrm{ca} 500$ to 1900 species (Lambdon et al. 2008). The number of alien species in Poland is thought to be 939, representing $\mathrm{ca} 27 \%$ of the flora (Tokarska-Guzik et al. 2012). This number includes over 370 kenophytes and 394 ephemerophytes. The proportion of anthropophytes in the local floras of Poland varies. It often depends on the accessibility and number of anthropogenic habitats. The history and mechanisms of non-native species dispersion have been treated by many authors (e.g., Kornaś 1990; Tokarska-Guzik 2005; Bartoszek et al. 2006). The species that have widened their range are most frequently kenophytes, while the majority of settled plants are strictly confined to ruderal habitats (Kornaś 1990).

Gypsophila perfoliata L. (Caryophyllaceae) was first found in Poland in the 1950s (Kuc 1958). Most of its few known localities were associated with railway stations where iron ore was offloaded on the way to steel mills from the Kryvyi Rih

\footnotetext{
1 Corresponding author
}

region in Ukraine. A new locality was found in 2013 next to the dual-carriageway section of the Kraków-Zakopane road in the Western Carpathians (southern Poland). Discovery of this new habitat for the species in Poland, and the strong possibility that it will widen its range, prompted us to undertake studies of its distribution and status.

\section{MATERIAL AND METHODS}

Based on published information (Kuc 1958; TrzcińskaTacik 1966, 1979; Święs \& Wrzesień 2002), herbarium records (KRA, KRAM), unpublished data and our own research, we determined the current distribution of Gypsophila perfoliata in Poland. We reviewed the status of this species using existing lists (Rostański \& Sowa 1987; Zając et al. 1998; Urbisz 2011; Tokarska-Guzik et al. 2012) and our research, and assessed its habitat conditions and population size. Phytosociological relevés (according to the Braun-Blanquet method) were made in order to determine its habitat spectrum.

\section{RESULTS AND DISCUSSION}

Gypsophila perfoliata is a yellow-green perennial plant, 30-120 cm tall (Fig. 1). It has an erect stem, numerously branched distally. Its succulent leaves are ovate or oblong-lanceolate, the basal 


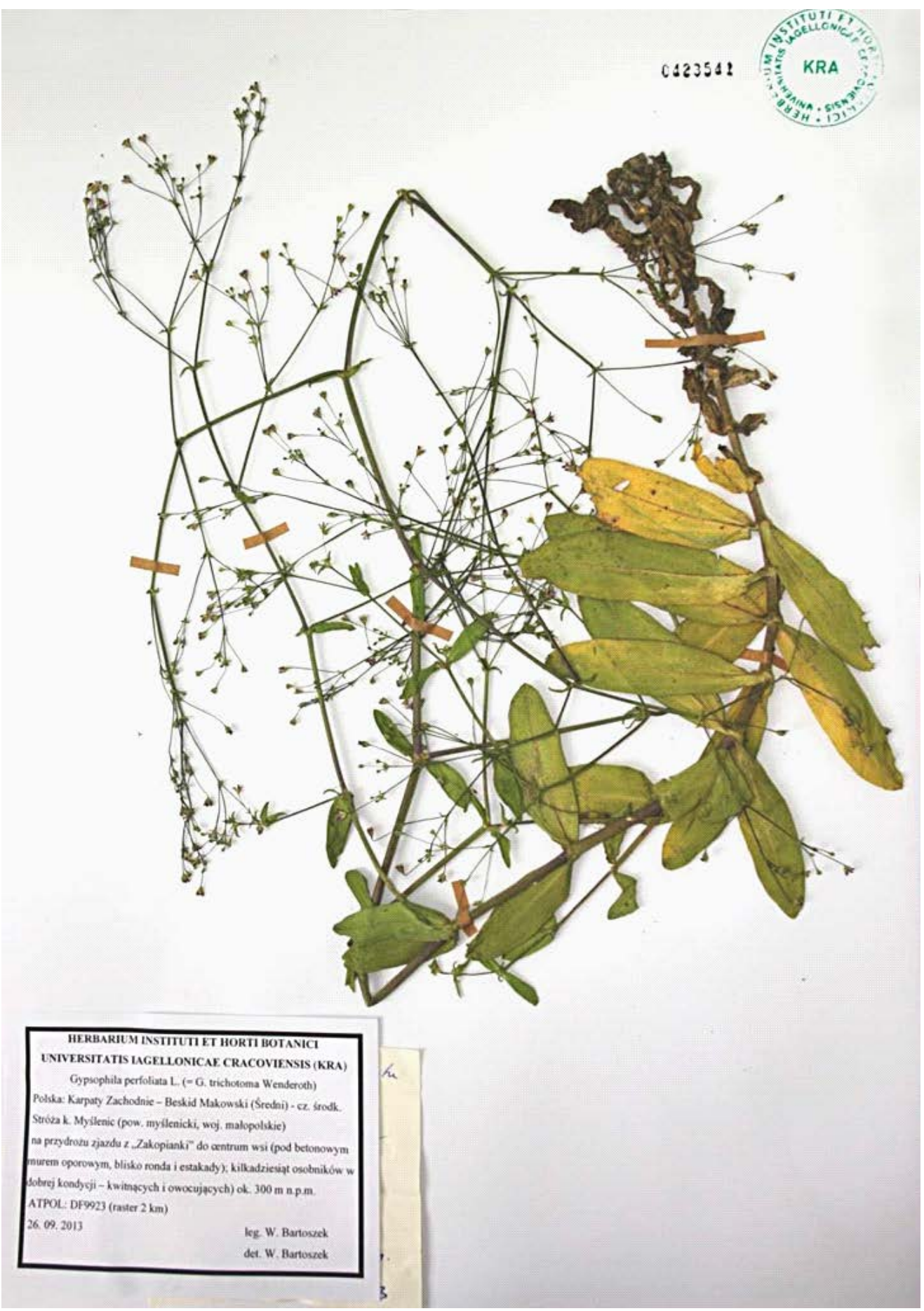

Fig. 1. Herbarium specimen of Gypsophila perfoliata L. from newly discovered locality in Myślenice, Western Carpathians, Poland (KRA 423541). 
ones being amplexicaul and slightly connate. The inflorescence (including calyx and pedicels) is glabrous but the stem below it and the lower leaves are usually glandular pubescent. The pedicels are $4-5 \mathrm{~mm}$ long, more than twice as long as the calyx. The petals are white to pale purple, emarginate, $c a 5 \times 2 \mathrm{~mm}$. The seeds are reniform, $1 \mathrm{~mm}$ long. The species flowers from July to September (Sychowa 1992; Barkoudah et al. 1993; Somlyay 2009).

The most closely related species is Gypsophila scorzonerifolia Ser. ex DC., native to the lower Volga River region and northern foreland of the Caucasus Mts, introduced to some European countries in the $19 / 20^{\text {th }}$ centuries (Somlayay 2009, and references therein), and not found in Poland to date.

Gypsophila perfoliata has natural localities in the continental parts of Eastern Europe and Western Asia (Kuc 1958; Jalas \& Suominen 1986; Sychowa 1992). It grows on saline soils (coastal dunes, semi-deserts, deserts, salt pans) as well as in steppe. As an unintentionally introduced and settled plant it occurs rarely in countries of Central and Eastern Europe such as Belarus (Trietyakov 1988; Parfenov 1999; Shimko 1999), Germany (Schnedler 1977; Sommerwerk et al. 2005), Hungary (Polgár 1926; Somlyay 2009), Poland (Kuc 1958), Slovakia (Dostál 1989; Majeková et al. 2014) and Romania (Chifu 2006).

The known localities of G. perfoliata in Poland are listed and briefly described below (Fig. 2).

1 - Ostrowiec Świętokrzyski, Wyżyna Małopolska upland; leg. M. Kuc 1956, (KRAM; Kuc 1958). ATPOL grid square: EE-69.

The species used to occur in large numbers at a railway transhipment depot and a nearby steelworks. This locality was confirmed in 2003 (Maciejczak 2003) and 2004 (leg. R. Piwowarczyk 2003 \& 2004, KRA; Piwowarczyk 2010). In 2014, despite an exhaustive search, the plant was not found at the railway station. However, it occurs very abundantly on overgrown siding tracks in the former steelworks area. The species was also recorded in a ruderal habitat (a post-smelting slag heap) in the immediate vicinity of the steelworks. The population size in 2014 was estimated at several hundred multiple-shoot tussocks.

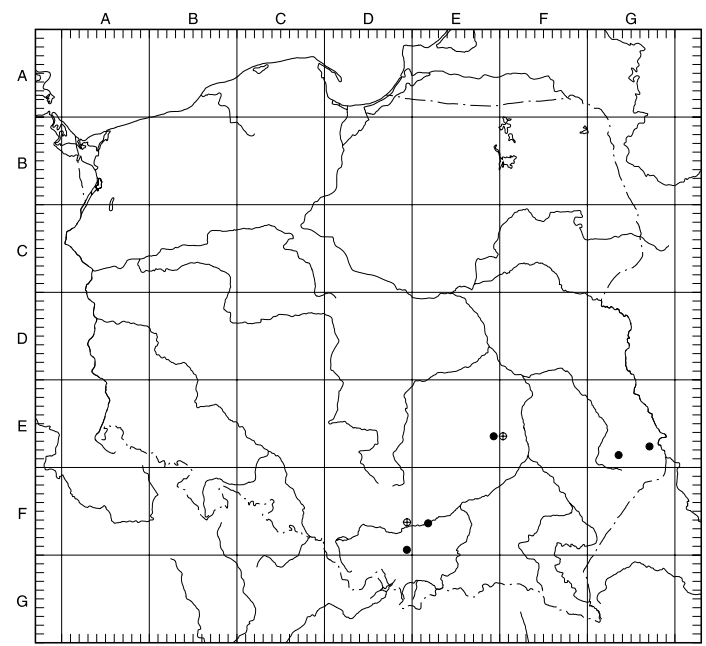

Fig. 2. Localities of Gypsophila perfoliata L. in Poland. ATPOL grid based on $10 \times 10 \mathrm{~km}$ cartogram unit. $\oplus$ - extinct localities, - existing localities.

The ruderal community with $G$. perfoliata is characterized by the following relevé:

Ostrowiec Świętokrzyski, ruderal vegetation patch on a slag heap near a railway siding, canopied by Betula pendula and Populus tremula. Area of relevé: $16 \mathrm{~m}^{2}$; date: 24.09.2014; plant cover: $60 \%$.

Gypsophila perfoliata 2.3, Ch. O. Sisymbrietalia (Cl. Stellarietea mediae): Chenopodium album agg. +, Conyza canadensis 2.1, Lactuca serriola + , Lepidium cf. ruderale + , Polygonum aviculare 1 , Setaria pumila + , Sonchus oleraceus + , Ch. O. Onopordetalia acanthii (Cl. Artemisietea vulgaris): Achillea millefolium 1, Artemisia vulgaris + , Cichorium intybus 2.1, Daucus carota + , Linaria vulgaris + , Medicago lupulina 2.3, Melilotus albus + , Tanacetum vulgare,$+ \mathrm{Ch} . \mathrm{Cl}$. MolinioArrhenatheretea: Lolium perenne + , Plantago maior 1, Poa compressa + , Taraxacum officinale + , Trifolium repens + , Others: Crataegus sp. (seedling) + , Diplotaxis $\mathrm{cf}$. tenuifolia +, Festuca sp. +, Veronica sp. +. Nearby: Amaranthus retroflexus, Atriplex nitens, Sisymbrium loeselii.

2 - Spoil mounds of the Kraków Soda Factory, Kotlina Sandomierska basin, leg. H. Trzcińska-Tacik 1961, (KRA; Trzcińska-Tacik 1966). ATPOL grid square: DF-69. This population is extinct due to habitat destruction (Trzcińska-Tacik 1979).

The former Kraków Soda Factory area is now fully built over and managed. The reappearance of G. perfoliata at this location is highly improbable. 
3 - Slag heaps near the Krzemionki Opatowskie Nature Reserve, Wyżyna Małopolska upland (Bróż 1991). ATPOL grid square: FE-60.

Gypsophila perfoliata was accidentally introduced to this site with smelter waste from the steelworks in Ostrowiec Świętokrzyski. The species was found neither by Piwowarczyk (2010) nor by us, despite a thorough search. Owing to secondary succession of shrub and forest vegetation (including artificial plantings), this heliophilous species is most likely extinct in the area.

4 - Zamość, northern part, Szopinek district, near a disused track of the former MetallurgySulphur Railway line (LHS), Wyżyna Lubelska upland (Święs \& Wrzesień 2002). ATPOL grid square: GE-83.

Several tussocks on sand-and-gravel substrate sparsely overgrown with vegetation.

5-Hrubieszów, Wyżyna Lubelska upland (Święs \& Wrzesień 2002). ATPOL grid square: GE-77.

In the central part of the offloading depot within the former Metallurgy-Sulphur Railway line (LHS). Several tussocks growing between the tracks on sand-and-gravel substrate loosely covered with vegetation.

6 - Kraków - Nowa Huta, Kotlina Sandomierska basin). On slag heaps in the former Lenin Steelworks (currently Arcelor Mittal Poland S.A.): Wadów, on a slag heap east of Nowa Huta railway station (leg. H. Trzcińska-Tacik 1998, KRA); Pleszów (leg. H. Trzcińska-Tacik 1997 \& 2000, KRA; Guzik 2003). ATPOL grid square: EF-61.

According to information from herbarium labels, the species used to occur in great abundance at both sites. Regrettably, the management did not grant us permission to enter the industrial area.

7 - Stróża near Myślenice, Beskid Makowski Mts, Western Carpathians, (leg. W. Bartoszek 2013, KRA). ATPOL grid square: DF-99.

In 2013, ca 100 large (multiple-shoot) tussocks were found at the roadside by the modernized Kraków-Zakopane dual carriageway, near the overpass and the exit to the village center from Myślenice. The locality was confirmed in 2014 and in 2015.

The community with $G$. perfoliata is characterized by the following relevé:
Area of relevé: $50 \mathrm{~m}^{2}, 300 \mathrm{~m}$ a.s.l., date: 1.10.2013, plant cover: c: $30 \%$; d: $80 \%$.

Gypsophila perfoliata 2.2, Ch. O. Sisymbrietalia $(\mathrm{Cl}$. Stellarietea mediae): Atriplex patulum,+ A. prostrata + , A. tatarica + , Chaenorhinum minus + , Chenopodium album + , Ch. glaucum + , Conyza canadensis,+ Fallopia convolvulus + , Lactuca serriola + , Polygonum aviculare,+ P. lapathifolium + , Sonchus arvensis 1, S. oleraceus + , Tussilago farfara,+ Ch. Cl. Artemisietea: Artemisia vulgaris 2.2, Echium vulgare,+ Urtica dioica + , Others: Ambrosia artemisiifolia + , Betula pendula $\mathrm{s}+$, Calamagrostis epigejos + , Cerastium holosteoides + , Hieracium cfr. sabaudum + , Larix sp. $\mathrm{s}+$, Leontodon autumnalis,+ L. hispidus + , Plantago maior + , Puccinellia distans 2.3, Salix purpurea + , Solidago virgaurea + , Taraxacum officinale + , Verbascum nigrum + , Bryum sp. 3.

Gypsophila perfoliata was classified as an ephemerophyte in Flora Polski (Sychowa 1992), after the list of ephemerophytes in Poland published by Rostański and Sowa (1987). The authors of the list of kenophytes in Poland (Zajacc et al. 1998) mention $G$. perfoliata among species of transitional status between ephemerophyte and kenophyte. In the checklist Flowering plants and pteridophytes of Poland (Mirek et al. 2002) it was accorded settled anthropophyte (kenophyte) status, as also in the latest study of non-native species in Poland (Tokarska-Guzik et al. 2012), where it was ranked among the epecophytes, that is, species settled only in ruderal habitats. It seems highly justified to change the status of this species. The locality in Ostrowiec Świętokrzyski, found nearly 70 years ago, has persisted to this day and its population is very abundant there. The localities on smelter slag heaps in Kraków were not documented by herbarium material until the 1990s and early $21^{\text {st }}$ century but they undoubtedly predate that time. Unpublished data (J. Guzik) contain records of $G$. perfoliata from Pleszów dating back to the 1980s. Perhaps it appeared in that area at about the same time as (or slightly later than) in Ostrowiec Świętokrzyski. Gypsophila perfoliata most likely was unintentionally introduced into Poland shortly after World War II with iron ore transports from the former Soviet Union (Kryvyi Rih region, Ukraine). The recently found population in Stróża, the first one in the Polish Carpathians, probably formed as 
a result of unintentional transfer of diaspores with smelting aggregate (from slag heaps) used there as building material for road construction.

Gypsophila perfoliata is spreading in Europe, mostly along railways and roads (e.g., Sommerwerk et al. 2005; Majeková et al. 2014). It colonizes anthropogenic habitats, particularly railway tracks. Much less frequently these include roadsides and industrial slag deposits, mainly on saline substrate. It may form initial anthropogenic communities together with native plants and other anthropophytes (especially associated with saline habitats). As reported by J. Guzik (personal information), it occurred on a slag heap in the Kraków-Pleszów district in such large numbers that it formed an independent community. To date, the occurrence of G. perfoliata in Poland is linked exclusively to anthropogenic habitats; it has not been noted to enter seminatural and natural plant communities. We suggest that the small number of $G$. perfoliata localities in Poland documented to date is associated with the requirements of the species: climatic (thermophilous) and soil conditions (halophilous), limited access to suitable localities (closed smelter areas), and biological traits (barochoric seeds). Regular monitoring of the $G$. perfoliata population is necessary.

In Germany the species was found in four types of plant communities: Spergulario-Puccinellietum, Calamagrostis epigejos community, Rubus community, Dauco-Melilotion (Sommerwerk et al. 2005). As the latter authors state, communities of Dauco-Melilotion have become increasingly common and widespread along railway lines and roadsides, and here G. perfoliata can find potential sites for colonization. As a halophilous species, $G$. perfoliata can use the anthropogenic habitats along roads, which require salt to be applied as part of winter maintenance. Global warming could also facilitate invasion from warmer regions. The recently noted boosted dynamics of alien plant ranges throughout Europe calls for closer observation of this potentially invasive species. One plant that exemplifies rapid colonization of such habitats in the twentieth century is Puccinellia distans (Jacq.) Parl., previously known to grow in Poland only on Baltic coastal and inland salt pans (Jackowiak 1996). This native halophyte has spread during the last 25 years throughout nearly the whole of Poland, becoming a common plant along major roads and lately also local ones, as well as in cities. It follows a similar pattern in other European countries (Weiner 1981; Haeupler \& Schönfelder 1989). A good example of expansion (in some areas invasion) in the last few years in Poland is the case of Ambrosia artemisiifolia L., a species known until recently only from railway sites (Tokarska-Guzik et al. 2011).

Acknowledgements. We thank Dr. Maxim Dzhus and Dr. Tatyana Dvirna for information about synanthropic localities of Gypsophila perfoliata in Belarus and Ukraine, and the two anonymous reviewers for helpful comments and suggestions on the manuscript.

\section{REFERENCES}

Barkoudah Y. I., Chater A. O. \& Akeroyd J. R. 1993. Gypsophila L. In: T. G. Tutin, N. A. Burges, A. O. Chater, J. R. Edmondson, V. H. Heywood, D. M. Moore, D. H. Valentine, S. M. Walters \& D. A. WebB (eds), Flora Europaea 1. $2^{\text {nd }}$ ed., pp. 219-222. Cambridge University Press, Cambridge.

Bartoszek W., Urbisz A. \& Tokarska-GuziK B. 2006. Polygonum polystachyum Wall. ex Meissner in Poland: status, distribution, habitats. Biodiversity: Research and Conservation 1-2: 86-88.

Bróż E. 1991. „Krzemionki Opatowskie” (“The Flints of Opatów") - the archeological reserve of inanimate nature in the province of Kielce. Chrońmy Przyr. Ojczysta 47(6): 27-38 (in Polish with English summary).

Chifu T., MÂNZu C. \& ZAmfirescu O. 2006. Flora si vegetatia Moldovei. 1. Editura Universităţii “Al. I. Cuza”, Iaşi.

Dostál J. 1989. Nová Kvétena ČSSR. 1 \& 2. Academia, Praha.

GuziK J. 2003. Dump of T. Sendzimir steelwork in Cracow as locality of interesting alien plant species. Archiwum Ochrony Środowiska 29(2): 13-19 (in Polish with English summary).

Haeupler H. \& Schönfelder P. (eds) 1989. Atlas der Farnund Blütenpflanzen der Bundesrepublik Deutschland. 2. Eugen Ulmer GMbH \& Co., Stuttgart.

JACKOWIAK B. 1996. Chorological-ecological model of spread of Puccinellia distans (Poaceae) in Central Europe. Fragm. Florist. Geobot. 41(2): 551-561.

Jalas J. \& Suominen J. (eds) 1986. Atlas Florae Europeae. 7. Caryophyllaceae (Silenoideae). Distribution of vascular plants in Europe. The Committee for Mapping the Flora of Europe \& Societas Biologica Fennica Vanamo, Helsinki. 
KoRnAŚ J. 1981. Mechanisms and effects of the human impact upon the flora. Wiadom. Bot. 25(3): 165-182 (in Polish with English summary).

Kornaś J. 1990. Plant invasions in Central Europe: historical and ecological aspects. In: F. DE CASTRI, A. J. HANSEN \& M. Debussche (eds), Invasions in Europe and the Mediterranean Basin, pp. 19-36. Kluwer Academic Publishers, Dordrecht.

KuC M. 1958. Gypsophila trichotoma Wend. in Central Poland. Fragm. Florist. Geobot. 3(2): 9-35 (in Polish with English summary).

Lambdon P. W., Pyšek P., Basnou C., Hejda M., Arianoutsou M., Esl F., Jarošík V. Pergl J. Winter M., Anastasiu P., Andriopoulos P., Bazos I., Brundu G., Celesti-Grapow L., Chassot P., Delipetrou P., JosefSSON M., Kark S., Klotz S., KoKkoris Y., KüHn I., Marchante H., Perglová I., Pino J., Vilà M., Zikos A., Roy D. \& Hulme P. E. 2008. Alien flora of Europe: species diversity, temporal trends, geographical patterns and research needs. Preslia 80(2): 101-149.

MaciejCZaK B. 2003. Anthropophytes in vascular flora of Ostrowiec Świętokrzyski. In: A. ZAJĄC, M. ZAJĄC \& B. ZEMANEK (eds), Phytogeographical problems of synanthropic plants, pp. 301-309. Institute of Botany, Jagiellonian University, Kraków.

Majeková J., Zaliberová M. \& Jehlík V. 2014. Interesting findings of the vascular plants in the railway junctions of southern Slovakia. Biodiversity: Research and Conservation Suppl. 1: 23.

Mirek Z., Pį̨Koś-Mirkowa H., Zając A. \& ZająC M. (eds) 2002. Flowering plants and pteridophytes of Poland a checklist. Biodiversity of Poland. 1. W. Szafer Institute of Botany, Polish Academy of Sciences, Kraków.

Parfenov W. I. (ed.) 1999. Opredelitel wysszych rastenij Belarusi. Dizain PRO, Minsk.

PIWOWARCZYK R. 2010. Vascular plants of the eastern part of the Iłża Foreland (Małopolska Upland). Prace Botaniczne 43: 1-344 (in Polish with English summary).

Polgár S. 1926. Neue Beiträge zur Adventivflora von Györ (Westungarn) III. Magyar Bot. Lapok 24: 15-23.

Rostański K. \& Sowa R. 1987. Alphabetical list of the ephemerophytes of Poland. Fragm. Florist. Geobot. 31-32 (1-2): 151-205 (in Polish with English summary).

Schnedler W. 1977. Pflanzen, von denen in der mitteleuropäischen Literatur selten oder gar keine Abbildungen zu finden sind. Folge II: Gypsophila perfoliata, scorzonerifolia, tomentosa. Göttinger Florist. Rundbr. 11(2): 21-26.
SHimko I. I. 1999. New and rare species for Belarusian Lake District. Vesnik Vitzebskaga Dzyarzhaynaga Universiteta 1(11): 72-79 (in Russian with English summary).

SomLyay L. 2009. Alien Gypsophila taxa in the flora of Hungary. Studia Bot. Hung. 40: 173-180.

Sommerwerk A., Partzsch M., Wesche K. \& Hensen I. 2005. Site conditions and association of the two adventive species Gypsophila perfoliata and G. scorzonerifolia (Caryophyllaceae) in central Germany. Hercynia N.F. 38: 263-286 (in German with English abstract).

Święs F. \& Wrzesień M. 2002. Rare vascular plants of the railway areas in Central-Eastern Poland. I. Lublin Upland, eastern part, Roztocze, Volhynia Upland. Ann. Univ. M. Curie-Skłodowska, Sec. C 57: 1-23.

Sychowa M. 1992. Gypsophila L. Łyszczec. In: A. JASIEwICZ (ed.), Flora Polski. Rośliny naczyniowe. 3: 241-246. Instytut Botaniki im. W. Szafera PAN, Kraków.

ToKARsKa-GuzIK B. 2005. The establishment and spread of alien plant species (kenophytes) in the flora of Poland. Uniwersytet Śląski, Katowice.

ToKarsKa-GuzIK B., BzDĘGa K., Koszela K., ŻABIŃSKa I., Krzuś B., Sajan M. \& SendeK A. 2011. Allergenic invasive plant Ambrosia artemisiifolia L. in Poland: threat and selected aspects of biology. Biodiversity: Research and Conservation 21: 39-49.

Tokarska-Guzik B., Dajdok Z., ZająC M., ZająC A., Urbisz A., DANiElewicz W. \& HoldyŃSKi C. 2012. Alien plants in Poland with particular reference to invasive species. Generalna Dyrekcja Ochrony Środowiska, Warszawa (in Polish with English summary).

TrietYaKov D. I. 1988. New adventive vascular plants for the flora of Belarus. Bot. Zhurn. 73(6): 903-910 (in Russian).

TRZCIŃSKA-TACIK H. 1966. Flora and vegetation of the spoil mounds of the Cracow Soda Factory. Fragm. Florist. Geobot. 12(3): 242-316.

Trzcińska-TaciK H. 1979. Flora synantropijna Krakowa. Prace Habilitacyjne, Uniwersytet Jagielloński 32: 1-278.

URBISZ A. 2011. Occurrence of temporarily-introduced alien plant species (ephemerophytes) in Poland - scale and assessment of the phenomenon. Wydawnictwo Uniwersytetu Śląskiego, Katowice.

WeINER E. 1981. Zur floristischen Erfassung von Umweltveränderungen. Wissenschaftliche Abhandlungen der Geographischen Gesellschaft der DDR 15: 101-109.

ZAJĄC A., ZAJĄC M. \& TOKARSKA-GUZIK B. 1998. Kenophytes in the flora of Poland: list, status and origin. Phytocoenosis. Suppl. Cartogr. Geobot. 9: 107-116. 